\title{
Environmentally sustainable versus aesthetic values motivating millennials' preferences for wine purchasing: evidence from an experimental analysis in Italy
}

\author{
Gianluigi Gallenti ${ }^{1 *}$ D, Stefania Troiano ${ }^{2}$, Francesco Marangon², Paolo Bogoni ${ }^{1}$, Barbara Campisi ${ }^{1}$ and
} Marta Cosmina ${ }^{1}$

\author{
* Correspondence: gianluigi. \\ gallenti@deams.units.it \\ 'Department of Economics, \\ Business, Mathematics and Statistics, \\ University of Trieste, Trieste, Italy \\ Full list of author information is \\ available at the end of the article
}

\begin{abstract}
The interest in wine produced in an environmentally friendly manner is increasing in the global market among both consumers and producers. Moreover, numerous labelling and certification systems have been introduced to guarantee environmentally friendly production. Consumers can consider some environmental attributes in relation to their purchasing decisions as components of their ethical demands; such consumer behaviours can drive wine production to more sustainable models. This change depends on many factors, such as consumers' willingness to pay for sustainable and ethical attributes and the effective communication of such attributes. Among consumers, young people belonging to the so-called millennial generation are the new wine consumers, and they represent an increasingly important segment of the global wine market. This study uses a choice experiment to investigate Italian millennials' preferences toward two ethical attributes of wine: 'carbon footprint claim' and 'winescape aesthetic'.

The findings show considerable heterogeneity among respondents, the majority of whom seem to be interested in the carbon footprint claim, even if a group of them prefer to pay a premium price to consume high-quality wines. Our results indicate that winescape aesthetic does not appear to be an important attribute in guiding respondents' preferences.
\end{abstract}

Keywords: Wine consumption, Carbon footprint, Winescape aesthetic, Choice experiment, Italian millennial generation

\section{Introduction}

\section{Background and aim of the study}

Nowadays, changes in consumer demands in many primary sector markets are constantly driving changes in the value chains that primary industries participate in (e.g. organic food, products with indication of origin, vegan food). There is an increasing expectation that products should have environmental sustainability credentials in their production process (Guenther et al. 2012), such as information about climate change impacts (Rousseau and Vranken 2013).

(c) The Author(s). 2019 Open Access This article is distributed under the terms of the Creative Commons Attribution 4.0 International License (http://creativecommons.org/licenses/by/4.0/), which permits unrestricted use, distribution, and reproduction in any medium, provided you give appropriate credit to the original author(s) and the source, provide a link to the Creative Commons license, and indicate if changes were made. 
Several environmental attributes are strictly related with wine production: organic production, greenhouse gas (GHG) emissions, water use, waste production, soil protection, landscape creation or conservation, local climate conditions, and terroir. It should be noted that some of these attributes are correlated, for example, local climate conditions and terroir.

Most of these attributes, especially local climate conditions, terroir, organic production, and water use, affect the intrinsic characteristics of grapes and therefore the quality of wine. At the same time, the whole wine supply chain, in a global context, strongly influences the environment, particularly in terms of GHG emissions, water use, and landscape, the main environmental externalities of the wine production system. (Bosco et al. 2011; Colman and Päster 2009; Cholette and Venkat 2009; Niccolucci et al. 2008; Pattara et al. 2015; Rugani et al. 2013; Santini et al. 2013; Soja et al. 2010; Waye 2008).

Consumer demand usually takes into account the different characteristics of the wine, such as price, origin, and production process, but also some environmental factors could be relevant in the purchase choices. Consumers' behaviour can be analysed as an ethical consumption phenomenon; this is defined as the purchasing decisions made by people concerned with not only the price of products and services but also with the political, social, and environmental consequences of their purchases (Carlsson et al. 2010, Coff et al. 2008; Cohen and Vandenbergh 2012; Delmas and Grant 2008; Guenther et al. 2012; Liebe et al. 2014; Roos and Tjarnemo 2011; Rousseau and Vranken 2013; Sudbury-Riley and Kohlbacher 2016).

Currently, among the different characteristics of ethical demands of wine, it is particularly interesting to analyse Italian consumers' attitudes toward two specific attributes: 'carbon footprint claim' and 'winescape aesthetic' (or 'landscape beauties'). This is because carbon footprint claim is linked to the pressing GHG emission issue (Rugani et al. 2013) and winescape aesthetic refers to the emerging importance of the agricultural landscape value (Tempesta et al. 2010). There is a lack of research about Italian millennials wine consumption behaviour about these two attributes of wine.

These elements of consumer demand, including ethical ones, can be analysed using the Lancaster approach developed in the so-called 'new theory of consumer demand' (Lancaster 1966), where consumers are not seeking to acquire goods themselves but the characteristics they contain.

It is necessary to recognize that consumers' willingness to pay (WTP) for the same ethical attribute may differ significantly from country to country depending on the social, cultural, and traditional contexts of the different countries; however, at the same time, it is possible to find some common trend (Liebe et al. 2014; McCluskey and Loureiro 2003; Sudbury-Riley and Kohlbacher 2016).

However, specific groups of consumers in different countries may have very similar attitudes toward some particular ethical attributes; such behaviour is driven by age, culture, social habits, or other common characteristics that mainly determine consumers' preferences, despite the existence of other relevant differences among people.

This is the case of millennials, the demographic cohort born between the early 1980 s to around 2000, who express their own cohort dynamics with common behaviours in different countries in relation to environmental commitment and consumption preferences (Bakewell and Mitchell 2003; Noble et al. 2009). They are 
expected to show such behaviour toward wine consumption as well (Teagle et al. 2010; Wolf and Thomas 2007).

Different methods can be used to estimate millennials' WTP for the two ethical attributes of interest of wine-carbon footprint claim and winescape aesthetic, among these some of the most used are contingent valuation method $(\mathrm{CV})$, conjoint analysis $(\mathrm{CA})$, and choice experiments (CE). In particular, $C E$ have been used most often in recent literature (Breidert et al. 2006; Louviere et al. 2010).

This study investigates whether young consumers, namely, millennials of age 18-34 years, select wines on the basis of carbon dioxide emission levels or winescape aesthetic. The aim is to estimate how millennials evaluate wine's aesthetic and environmentally sustainable attributes and to explore which one is prevalent.

\section{Literature review}

\section{Wine carbon footprint}

Nowadays, there is a general consensus among most climate scientists that GHG emissions generated by human activities are the main drivers of climate change.

Food production is one of the economic activities that pose major pressures on the environment. In particular, agriculture, forestry, and land use change are responsible for $20-24 \%$ of global greenhouse gas emissions. Agriculture activity alone is considered directly responsible of global GHG emissions for a percentage that is estimated from 10 to 12 to $17 \%$; an additional $7-14 \%$ is related to changes in land use. The contribution of the agri-food supply chain, including input suppliers for the agricultural sector, agriculture, food industry, logistics activities and transportation of goods, distribution, and waste management, is obviously much higher (Akaichi et al. 2016; Bertoni et al. 2018; OECD 2016; Smith et al. 2014).

This contribution is, in any case, expected to increase in the future owing to the growing demand for foods (Breustedt 2014; Smith et al. 2014). Consequently, many climate change experts have recommended the implementation of improved management practices in agriculture and the whole agri-food supply chain to increase the production of foods with lower GHG emissions (Van Doorslaer et al. 2015).

The carbon footprint (CF), defined as 'the total set of GHG emissions caused directly and indirectly by an individual, organization, event, or product,' is being used increasingly to effectively communicate sustainability efforts to consumers. This key indicator 'environmental sustainability' plays a primary role in environmental issues concerning farm activities and agricultural practices.

To determine opportunities for mitigating climate change, it is essential to be aware of the amount and sources of GHG emissions. One method for this is life cycle assessment (LCA) of a product. CF is a LCA that measures the GHG contribution from a product or activity (Čuček et al. 2012; Fang and Heijungs 2015). CF often comprises emissions during the whole chain from raw material, production processes, transport, trade, and use to disposal or recycling (Soja et al. 2010). A $\mathrm{CF}$ value of 0 means that an activity is carbon neutral, that is, it does not contribute to global warming because it results in no net release of carbon dioxide to the atmosphere. Carbon neutrality can be achieved by minimizing GHG emissions and then balancing the rest of the emissions with an equal amount of carbon offsets by 
supporting third-party-certified external projects for renewable energy with the generation of carbon credits (Rugani et al. 2013).

In this scenario, it is interesting to note that viticulture is one of the most diffused cultivations in the world, and therefore, wine and grapes are one of the top products in the agricultural market (OIV 2018). Total worldwide wine consumption has increased in recent years.

In particular, in 2016, worldwide wine consumption was estimated at 242 million $\mathrm{hl}$, quantity that has stabilized since the 2008 economic crisis. The USA, with almost 32 million hl, confirmed its position as the largest consumer country in the world since 2011, followed by France ( 27.0 million hl), Italy $(22.5$ million hl), Germany (20.2 million hl), and China (17.3 million hl). In recent years, consumption had remained relatively stable in France, Italy, and Spain, while it has increased in the USA and China (OIV 2018, 2019).

The wine supply chain is increasingly characterized by industrial processes, innovation, and the global market. Therefore, it contributes to GHG emissions and climate change. As a result, the environmental relevance of the wine industry has been increasing in recent years (Santini et al. 2013), and several CF assessments of viticulture and winemaking products have been performed (Colman and Päster 2009; Delmas and Grant 2008).

Many studies of the wine industry have investigated (a) whether CF is adequate to evaluate the environmental impact of wine production and (b) whether it is possible to identify winery processes that are most responsible for GHG emissions. Such studies have shown that, overall, the CF methodology is useful for identifying environmental hotspots (primarily, the agricultural phase) and improvement opportunities for the wine industry, even though it actually provides information for only one environmental impact category. At the same time, some methodological issues were identified, especially because of the different modelling frameworks adopted and the consequent inclusion or exclusion of, for example, packaging, end of life of bottles, and recovery and recycling processes (Rugani et al. 2013).

In the state-of-the-art, a wide range of CF applications in the wine industry remains unexplored, and recently, there has been an intense debate in this field about methodological and conceptual issues, the adequacy of international standardization tools, and the role of eco-labelling in influencing consumers' behaviours (Benedetto 2010; Bosco et al. 2011; Capitello et al. 2016; Carballo Penela et al. 2009; Cholette and Venkat 2009; Niccolucci et al. 2008; Pattara et al. 2012; Rugani et al. 2013; Santini et al. 2013; Waye 2008).

\section{Winescape aesthetic}

According to the European Council, the European landscape convention (Council of Europe 2000) defined landscape as 'part of the territory, as it is perceived by the populations, whose features come from natural and anthropic factors and their interactions'. Indeed, this definition refers to the close linkage between men, their behaviour, and their land, but it also connects a territory with man's common life. Therefore, the reference made to landscape here refers not only to the beauty of landscapes as promoted by the media but also to common places that hold the history and culture of a region. 
Men and their land are then the origin of a landscape, of which human behaviour is a necessary feature. Our surroundings have their natural features, but only a dialogue between man and nature can increase a landscape's value. Tempesta (2014) pointed out that the rural landscape is always the result of the layering and overlaying of human interventions in the past. Therefore, a vineyard is one of the elements forming a landscape (so-called 'iconems'), and it often becomes a revaluing and distinctive feature of it.

A vineyard, therefore, becomes a landscape and, as such, possesses a capacity for transmitting feelings linked to the distinctive characteristics of the territory. In fact, this ability to communicate arises from the strong identity that some areas give to wines. Therefore, wine production characterizes a landscape with a vineyard, and this economic activity creates not only an agri-food product but also a positive externality, namely, the winescape aesthetic. At the same time, the 'winescape' characterizes the wine produced in the area, and therefore, the wine can communicate characteristics and feelings. Johnson and Bruwer (2007) stated that the winescape is multi-dimensional as it, in turn, encapsulates the interplay of several features such as vineyards, wineries and other physical structures, wines, natural landscape and setting, people, heritage, and town(s) and buildings and their architecture and artefacts within. They referred to the regional wine brand image as a held perception (or belief) about a bounded wine area space, the elements of which are 'glued together' by interrelated winescape elements.

However, the most important dimension of the winescape is the region's natural beauty/setting (landscape) (Bruwer and Lesschaeve 2012; Bruwer et al. 2014) or winescape aesthetic. Moreover, according to Quintal et al. (2015), the winescape aesthetic and wine value are also significant attributes that influence wine tourist attitudes. In addition, winescape aesthetic is important in wine quality perception. According to Tempesta et al. (2010), the perception of the landscape feature of production is quite a complex phenomenon as it involves numerous components of the human mind, and it has an important emotional value. In fact, international literature (Tempesta et al. 2010; Veale and Quester 2008) has demonstrated that associating wine to an image with a greater visual impact can positively affect the perception of wine quality.

As with other positive externalities, the winescape needs either a public support system (public payments) and/or a premium price that consumers are willing to pay for this attribute. Therefore, it is necessary to analyse consumers' choices to estimate the market potential of this attribute while also taking into account the fact that the landscape attribute suffers in the absence of a specific certification system.

\section{Millennials' preferences for wine purchasing}

Millennials, which refers to those born roughly between 1980 and 2000, represent an important segment of the wine market in several countries. In fact, the consumption patterns of this new generation are having an increasingly relevant influence on both total and per capita wine consumption. Several data and researches show the trends and influences of millennials on wine consumption in different countries. Millennials appear to drink wine less frequently, consume it more often in social on-premise settings, have slightly higher WTP, and consume a higher share of white wine than other 
generations. Most of these differences can be linked to an age effect, suggesting that their wine behaviour will change over time (Barber et al. 2008).

Several researches have analysed millennials' behaviours, and this has contributed to the question of whether generational differences are similar in different markets or whether they are country-specific (Fromm and Garton 2013; Nowak et al. 2006; Nowak and Newton 2008; Olsen et al. 2007; Wolf and Thomas 2007).

Today's consumers, and millennials in particular, play an important role in the global fight against climate change. In fact, even relatively small changes in their consumption could significantly reduce GHG emissions. The CF label allows consumers to make more informed purchases as also it gives them the option of choosing products with lower GHG emissions.

Although several studies and surveys have shown that millennials have a positive purchasing attitude toward environment-friendly products and that they are willing to pay a premium for low-CF products, little is known about whether they consider the environmental impacts of food products when shopping (Capitello et al. 2016; Pomarici and Vecchio 2014, Teagle et al. 2010).

At the same time, while numerous studies have revealed that the highest-rated factor for millennials when purchasing food is appearance, there is no evidence about the importance of the winescape aesthetic in drawing millennials' attention and influencing both the quality perception of wine and their purchasing behaviour. Landscape perception is a fairly complex phenomenon, and it involves both numerous components of the human mind as well as an important emotional value (Tempesta et al. 2010).

\section{Methods}

In our research, we conducted a face-to-face questionnaire survey in 2015 among Italian millennials. Before developing the questionnaire and, in particular, the CE and analysing millennials' preferences toward wine, we formed a focus group of 50 consumers and conducted a pilot study during the process of designing and filling the questionnaire. Focus group discussions were used to obtain information about the dimensions of the quality of wine that are important to individuals when choosing this product.

The questionnaire included questions about the respondents' socioeconomic characteristics, their wine-related consumption habits, and their specific knowledge and perception of the wine product. In addition, considering the aim of our research, we included a CE.

Before the survey, the interviewers were trained in survey administration. We administered the questionnaire to university students enrolled at the University of Trieste and University of Udine, both of which are located in the Friuli Venezia Giulia Region in northeast Italy. We obtained 587 completed questionnaires. No financial incentives were offered to the students for completing the questionnaire.

\section{CE methodology}

We conducted a CE to define not only the ordinal ranking of preferences but also the WTP for the key characteristics of the product. A CE approximates the real-world purchase behaviour, and therefore, it is widely used in economic research to study the 
valuation of public and private goods, including the environmental characteristics of a product (Carlsson et al. 2010; Hanley et al. 1998).

As is well known, CEs are one of the most widely used methods to estimate consumers' preferences for specific attributes of goods. The basic idea behind CE methods is that goods can be described as a bundle of different product attributes; each combination of these characteristics results in a different product, and survey respondents are asked to evaluate these changes (Hanley et al. 1998).

In particular, adopting CE consumers' WTP is measured indirectly, and respondents are forced to make trade-offs between the different product attributes. The CE design allows researchers to estimate the effect of each product attribute on respondents' product evaluations or product choices independently (Luce 1959; McFadden 1974).

Statistical analyses of the responses obtained from CE are used to estimate the marginal values of the attributes of a good; these represent the premium price that consumers are willing to pay for the characteristics they desire. Therefore, this study used CE to estimate consumers' WTP by using data obtained from a field experiment through face-to-face interviews.

In detail, we estimated the WTP for the attribute level by dividing $\beta$ coefficients by Bprice

$$
\mathrm{WTP}=-\beta / \beta \text { price }
$$

With reference to consumer demand, it is necessary to note that this approach means the adoption of the so-called new consumer demand theory (Lancaster 1966), and consequently, there exists the operational problem of estimating consumers' WTP for specific product attributes. As is well known, the Lancaster approach is an evolution of the traditional microeconomic theory of demand, in which the utility of goods is derived from their characteristics (and not from the goods per se); therefore, the utility of product alternatives is a latent construct that only exists in the minds of individual consumers. Researchers cannot observe this directly. Nonetheless, indirect measurement techniques can be used to explain a significant part of the latent utility construct. However, the error component determined by additional unobservable attributes, measurement errors, and variation between individual consumers remains unexplained.

First, this study used a multinomial logit model (MNL) in which consumers are assumed to be homogeneous. Moreover, considering that consumers are widely recognized as heterogeneous in their taste and preferences (Wedel and Kamakura 2000), we used a latent class (LC) model that assumes hidden latent classes for consumers and products.

In fact, although Millennials could be expected to show homogeneous behaviour toward wine consumption, according to the findings of Elliot and Barth (2012) their preferences are different in many ways.

Therefore, a basic LC model appears useful to investigate the sources of heterogeneity in preferences across classes of Italian millennials and to estimate class-specific WTP values for the identified attributes of wine. By introducing an LC model, the latent consumer and product clusters can be modelled.

Researchers who are interested in individuals' preferences for consumer products (or any behavioural alternatives) have to study their preferences for a product's attributes. 
Wine products can be characterized by different attributes such as price, origin, certification, CF claim, and winescape.

This approach combines insights from the characteristics theory of value (Lancaster 1966) that assumes that individuals do not derive utility from a product per se, but from a product's characteristics as well as from the random utility theory (RUT) (McFadden 1974). RUT models consumers' preferences among mutually exclusive discrete alternatives by drawing a real-valued score on each of them (typically independently) from a parameterized distribution and ranking these alternatives according to scores models.

Consumers typically have only basic knowledge of wine and therefore, information plays an important role. So the label information and certification logo are important means to convey and ensure the existence of the characteristics desired by consumers.

The theoretical basis for this aspect is the economics of information (Akerlof 1970; Stigler 1961). In particular, Akerlof was the first to show that asymmetric information, such as uncertainty about the quality of a good, can cause a market to degenerate into an exclusively low-quality product market.

\section{Experimental design}

A focus group involving 20 stakeholders (both private citizens and public institutions) was formed to identify the relevant attributes for the CE design. In detail, a number of candidate attributes were derived from a literature review and discussed, refined, and tested during the focus group. In addition, a pilot study was conducted in the process of designing the questionnaire format, which consists of two components. The CE was one part of the questionnaire. A white wine called 'Friulano' produced from the Sauvignon Vert (also known as Sauvignonasse) grape from Friuli Venezia Giulia, a region in Northeast Italy bordering Austria and Slovenia, was selected. The CE considered five attributes. For a wine bottle alternative, the attributes and attribute levels were considered carefully during the preliminary focus group discussions to ensure that both the scenarios closely describe the reality of the market and that respondents were familiar with them. We included price level, origin, production method (winescape), carbon footprint labelling, and quality certification/denomination of origin (e.g. Denominazione di Origine Controllata e Garantita (denomination of controlled and guaranteed origin, DOCG), Denominazione di Origine Controllata (denomination of controlled origin, DOC)) (Table 1).

The 'price' for each bottle alternative was presented on three levels. The middle level reflected the average retail price of the Friulano, whereas the two other price levels

Table 1 Attributes and attribute levels used in CE

\begin{tabular}{ll}
\hline Attribute & Levels \\
\hline Price (€/bottle) & $4,8,12$ \\
Origin & Collio, Friuli Venezia Giulia region, other Italian regions \\
Winescape & Yes, no \\
Carbon footprint labelling & Yes, no \\
Quality certification & 'table wine', DOC, DOCG \\
\hline
\end{tabular}

Source: own elaboration 
were set at $\pm 35 \%$ of the average price. These correspond, respectively, to the wine price in restaurants, wine bars, vinotheques, and bars, and to the retail price in case of discount or special offers.

The country of 'origin' attribute assumed one of three levels: produced in Collio, an area in the Friuli Venezia Giulia region; produced in the Friuli Venezia Giulia region; and produced in other Italian regions.

The winescape was represented in the CE, if present, by an image of a rural landscape with a vineyard, a typical agricultural landscape of Friuli Venezia Giulia region.

Carbon footprint labelling attribute was indicated as present or absent.

Three types of 'quality certification' were considered in this survey: 'table wine', DOC, and DOCG.

As is well known, the geographical indication of wine is a distinctive sign used to identify a product as originating in the territory of a particular country, region, or locality where its quality, reputation, or other characteristic is linked to its geographical origin. In this context, we refer to EU legislations; other countries have also adopted similar regulation (e.g. Australia). Nowadays, EU labels such as protected designations of origin (PDO) and protected geographical indications (PGI) or the Italian labels DOCG and DOC are well known among Italian wine consumers who recognize these certifications.

An orthogonal fractional factorial design was then generated using $\mathrm{SPSS}^{\circ}$ software, with 18 alternatives (or profiles) selected. The profiles were randomly combined into six sets of choice, the same for each respondent. Each respondent was asked to compare three wine bottle options plus the opt-out alternative and to choose the option they preferred. To simulate a realistic choice context, the 'none of these' alternative was included in the choice sets to give the consumers the freedom of choice that they have in real market situations, where they can also decide not to purchase any bottle at all. Each interviewee was informed that, except for these attributes, the chosen bottle had no difference in any other aspects, in particular no other indicators about characteristics of the products were on the figures (wine producer, vintage label, alcohol content, year of production, or other similar information). In addition, they were asked to consider the choice tasks as separate situations and to answer each of them.

\section{Results and discussion}

We received 587 fully filled questionnaires, and all of them were used for the statistical analysis. Of the 587 respondents, almost $50 \%$ were women. The average age of the respondents was approximately 21 years, with a median of 21.6 years. More than $80 \%$ not having a wine expert in their family (Table 2). Among all respondents, over $92 \%$

Table 2 Sample characteristics

\begin{tabular}{lll}
\hline Gender & Female & Male \\
& $50.09 \%$ & $49,91 \%$ \\
Years old & $<21$ & 21 and over \\
& $43.17 \%$ & $56.83 \%$ \\
Wine expert in your family & Average age & 21.64 \\
& Yes & No \\
& $19.08 \%$ & $80.92 \%$ \\
\hline
\end{tabular}

Source: own elaboration 
believed that carbon dioxide $\left(\mathrm{CO}_{2}\right)$ emissions are a problem, and over $55 \%$ consider this a relevant problem (important or very important) but the great majority $(85.2 \%)$ did not know about CF measures. Over $80 \%$ know the meaning of GHG (Table 3).

Data were analysed using NLOGIT ${ }^{\circ}$ software version 4.0. Table 4 shows the estimation results of the MNL and LC models. Consecutive models were estimated to decide the optimal number of latent classes. We chose an LC model with five classes as the best solution based on a comparison of the log-likelihood (LL) function, Akaike information criterion (AIC), Bayesian information criterion (BIC), and Hannan-Quinn information criterion (HQIC) (Table 5).

All parameters of the MNL model including the alternative specific constant (ASC) estimates are significant except for the winescape. The attribute price of the base model is negative, as expected. It is interesting to note that respondents preferred CF certification when choosing wine. However, we must consider the fact that the aim of the survey could have influenced respondents' answers or increased their awareness. In fact, the interviewees were asked to state their knowledge of and opinion about CF in the first part of the questionnaire. Then, in the second part of the questionnaire, respondents were asked to express their preferences declaring their choices among alternatives proposed.

The LC model confirms the MNL results, and it highlights a differentiated set of preferences among the respondents. Specifically, class 1 consisted of $52.2 \%$ of the respondents. The positive coefficients of CF certification on the bottle indicates they were mainly interested in choosing ethical products.

We refer to members of class 1 as 'environmentally conscious consumers'. Our results note that for some insignificant price coefficients (at the 5\% level), the WTP value of the corresponding attributes could not be estimated. These insignificant coefficients indicate that respondents are indifferent between the levels of that attribute, and therefore, the WTP is assumed to be zero.

Class 2 consisted of $11.6 \%$ of the respondents. They were negatively affected by the local origin of wine (negative WTP), maybe because of their main trust in certification. This group's positive coefficients for high 'quality certification' indicates that they appreciated high-quality wines and had WTP of $€ 6.25$ and $€ 3.98$ for DOCG and DOC wines, respectively; these WTP values are not so high because the respondents' incomes are probably not so high. These respondents are 'quality wine conscious consumers'.

Respondents in class 3 were 'local origin sensitive consumers' (5.8\%) and included those who preferred the local origin of wine while seeming to be indifferent to the other attributes considered in our study. In fact, it is interesting to observe how the

Table 3 Knowledge of GHG

\begin{tabular}{lll}
\hline & Yes & No \\
\hline Importance of the greenhouse gas (GHG) emissions & $92.81 \%$ & $7.19 \%$ \\
$\quad$ Important or very important & $55.39 \%$ & $44.61 \%$ \\
Knowledge of CF label (declared) & $14.68 \%$ & $85.32 \%$ \\
Knowledge of CF label & $80.00 \%$ & $20.00 \%$ \\
(verified through multiple choice question) & & \\
\hline Source: own elaboration & &
\end{tabular}




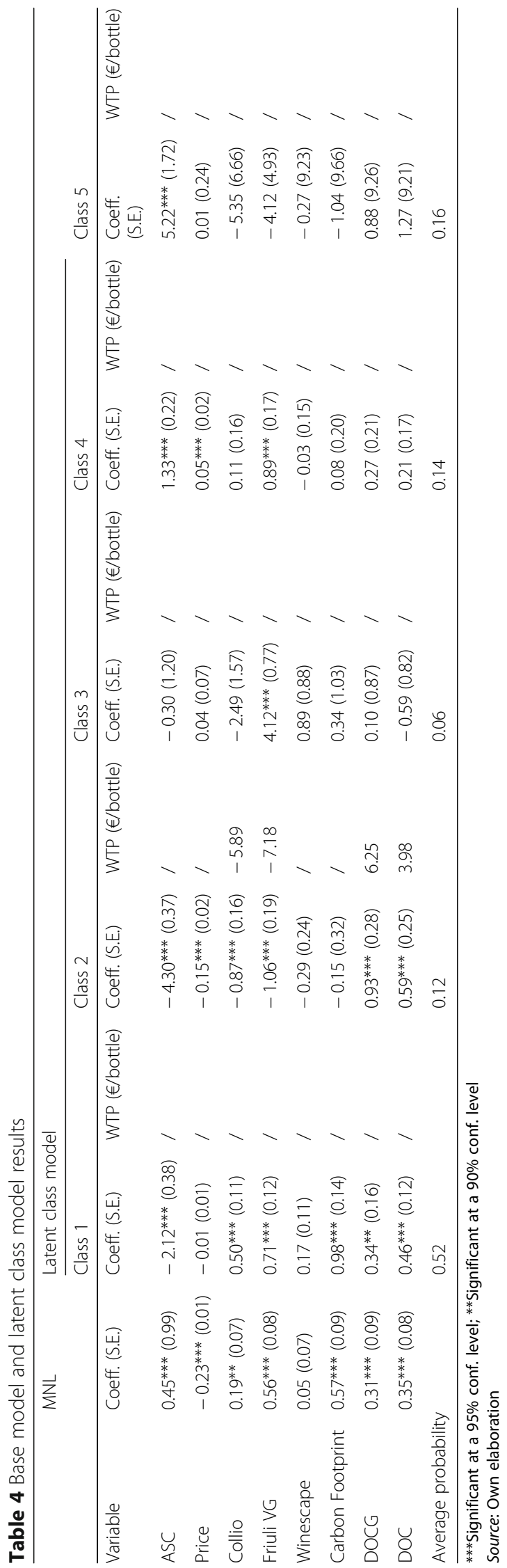


Table 5 Latent class model statistics

\begin{tabular}{lllll}
\hline & Latent class model 2 & Latent class model 3 & Latent class model 4 & Latent class model 5 \\
\hline $\mathrm{LL}$ & -3593.740 & -3464.954 & -3424.679 & -3360.037 \\
$\mathrm{AIC}$ & 2.056 & 1.990 & 1.972 & 1.941 \\
$\mathrm{BIC}$ & 2.088 & 2.036 & 2.034 & 2.018 \\
$\mathrm{HQIC}$ & 2.069 & 2.006 & 1.994 & 1.969 \\
McFadden pseudo $R^{2}$ & 0.26 & 0.28 & 0.29 & 0.31 \\
\hline
\end{tabular}

Source: own elaboration

coefficients for this class are not significant $(p>0.05)$ apart from the Friuli Venezia Giulia origin.

Respondents in class 4 were 'price low sensitive consumers' (14.1\%) and differed from the other segments in that the coefficient of the price variable was positive. Although these results could not be justified in economic terms for normal goods, it is possible to find a positive relationship between price and quantity, in a limited section of the demand curve, in the case of luxury goods. In these cases, for the consumer, the price is a proxy for quality. However, this implies that the higher the price, the higher is the probability of purchasing a given wine ceteris paribus. In addition, it is also plausible that respondents are not the persons responsible for purchasing wine and are not used to considering price in purchasing decisions.

Respondents in class 5 were 'not interested in wine products' (16.3\%) and had a positive and statistically significant ASC, that indicates strong preferences for no choice; probably, this group does not consume wine or does not usually purchase wine.

In a preliminary step of the analysis of data, we have included both sociodemographic and behavioural variables in the LC model to improve the class probability explanation; however, we found that they were not significant. CF-related questions included in the first part of the questionnaire. However, we cannot determine what happens when emotions take over in real life, such as when one purchases a bottle of wine with the image of a beautiful landscape. This cannot be directly measured in this CE, although it is to a certain extent captured in the random utility component. Consequently, it may be possible to state that the real effect exercised by the winescape aesthetic could be significant as an advertisement.

The potential of CF labelling in food products to change consumer behaviour has been recognized (Cohen and Vandenbergh 2012; Vanclay et al. 2011), and the practice of carbon labelling is likely to become increasingly important (Roos and Tjarnemo 2011).

Nevertheless, consumers need more information about specific characteristics that labels ensure (Troiano et al. 2016). Owing to the lack of an international methodology, there is no consistency in 'carbon footprint/carbon neutral' claims currently being made by wine companies. The credibility of these claims is threatened by multiple standards and by the lack of accurate baseline data needed to develop a greenhouse gas inventory for wine production.

According to the Akerlof theorem (1970), the adverse effects of asymmetric or incomplete information lead to an 'adverse selection' and to an inefficient market equilibrium, which emphasizes the importance of an effective labelling system (Banterle and 
Stranieri 2008). In detail, also our findings demonstrate that information presented in the label could be useful in supporting the purchase decision process.

At the same time, identifying other consumer demands could contribute to incentivize the adoption of carbon reduction strategies. Current strategies include the adoption of traditional processes (van Rikxoort et al. 2014), organic systems (Aguilera et al. 2014), localization of consumption (Cleveland et al. 2011), and reduction in waste (Svanes and Aronsson 2013).

In summary, according to other researches, consumers in developed countries are increasingly interested in the consumption of products incorporating ethical aspects; however, our study's results suggest that they need more information about CF products.

Most millennials consider themselves global citizens who have a responsibility to make the world better. Furthermore, while millennials might not label themselves as environmentalists, they feel strongly about environmental policies (Capitello et al. 2016; Moreno et al. 2016).

While other studies concerning other products with environmental attributes stated that respondents were willing to pay a significant premium price for the certified goods, our results suggest that a consistent group of millennials show a lacking attitude toward these characteristics at the purchasing stage.

Moreover, we noticed that respondents tend to prefer wine that is produced in a specific local area or that has a quality certification.

Numerous limitations should be noted. First, the use of some questions about CF might have biased the estimates of CE. Then, our survey was carried out in northeast Italy. Moreover, we choose not to repeat the survey among the same respondents in different periods. Finally, it is necessary to remark that plausible respondents are not the persons responsible for purchasing wine and so price could be not so important for them.

Despite these limitations, our findings are particularly useful for marketers and entrepreneurs because studies that compare the different sustainability aspects of wine are particularly scant, and no research has yet focused on Italian millennials.

Future studies, however, will have to deal with the increasingly complex market interactions linked to the entire life cycle of winemaking. A comprehensive discussion concerning the benefits of the CF indicator may be provided to both producers and consumers to consider the need to reduce uncertainties and misinterpretations within a growing globalized wine market.

Therefore, it is interesting to develop these first results to carry out other research on this issue. In particular, it is interesting to investigate (a) the behaviour of other millennial groups, such as those in other Italian regions, in other countries (also using web tools to carry out a questionnaire survey), or in other contexts beyond universities and (b) changes in the behaviour of the respondents' cohort in years. It is also interesting to study the influence of the question about the knowledge of CF or winescape aesthetic labelling included in the questionnaire on the choice in the $\mathrm{CE}$, and the relationship between the answers provided in the questionnaire and the effective purchases in the market. garantita; GHG: Greenhouse gas; HQIC: Hannan-Quinn information criterion; LC: Latent class; LCA: Life cycle assessment; LL: Log-likelihood function; MNL: Multinomial logit model; WTP: Willingness to pay 


\section{Acknowledgements}

Special thanks go to the members of the focus group and to the university students who collaborated by filling the questionnaires. The authors want also to thank the anonymous reviewers for their insightful comments. Any remaining errors are the responsibility of the authors.

This paper has been selected as a best paper of the 53rd SIDEA Conference in San Michele all'Adige and Bolzano (22-24 September 2016). It has been accepted for publication in this journal following the usual revision process.

\section{Issues relating to journal policies}

Not applicable.

\section{Authors' contributions}

The work is the result of the full collaboration of all the authors. All the authors have made substantial contributions to the conceptualization and design of research, to the acquisition of data, to the interpretation of results, and to the drafting and critical review of the manuscript. However, GG wrote the paragraphs for the 'Background and aim of the study' and 'Winescape aesthetic' sections. ST wrote the 'Results and discussion' section. FM wrote the 'Conclusions' section. PB wrote the paragraph for the 'Wine carbon footprint' section. BC wrote the paragraph for the 'Millennials' preferences for wine purchasing' section. MC wrote the 'Methods' section. All authors read and approved the final version of the manuscript.

\section{Funding}

This research was conducted within the framework of the research projects FRA (Fondo per la Ricerca di Ateneo) 2016-University of Trieste.

\section{Availability of data and materials}

All data were acquired and elaborated by the authors. Data supporting the research are available by requesting to the authors.

\section{Competing interests}

The authors declare that they have no competing interests.

\section{Author details}

${ }^{1}$ Department of Economics, Business, Mathematics and Statistics, University of Trieste, Trieste, Italy. ${ }^{2}$ Department of Economics and Statistics, University of Udine, Udine, Italy.

Received: 24 September 2018 Accepted: 11 June 2019

Published online: 04 July 2019

\section{References}

Aguilera E, Guzmán G, Alonso A (2014) Greenhouse gas emissions from conventional and organic cropping systems in Spain. II. Fruit tree orchards. Agron Sustain Dev 35(2):725-737. https://doi.org/10.1007/s13593-014-0265-y

Akaichi F, Nayga RM Jr, Lanier Nalley L (2016) Are there trade-offs in valuation with respect to greenhouse gas emissions, origin and food miles attributes? Eur Rev Agric Econ 44(1):3-31. https://doi.org/10.1093/erae/jbw008

Akerlof GA (1970) The market for "lemons": quality uncertainty and the market mechanism. Q J Econ 84(3):488-500. https:// doi.org/10.2307/1879431

Bakewell C, Mitchell WW (2003) Generation Y female consumer decision-making styles. Int J Ret Distr Manage 31(2):95-106. https://doi.org/10.1177/0972262915610853

Banterle A, Stranieri S (2008) The consequences of voluntary traceability system for supply chain relationships. An application of transaction cost economics. Food Policy 33(6):560-569. https://doi.org/10.1016/j.foodpol.2008.06.002

Barber N, Dodd T, Ghiselli R (2008) Capturing the younger wine consumer. J Wine Research 19(2):123-141. https://doi.org/10. $1080 / 09571260802622225$

Benedetto G (2010) Life cycle environmental impact of Sardinian wine. In: EAAE Seminar 'Sustainability in the food sector: Rethinking the relationship between the agro-food system and the natural, social, economic and institutional environments', Capri, Italy, June $30^{\text {the }}$-July $2^{\text {nd }}, 2010$

Bertoni D., Cavicchioli D., Donzelli F, Ferrazzi G., Frisio D.G., Pretolani R., Ricci E.C., Ventura,V. (2018). Recent contributions of agricultural economics research in the field of sustainable development. Agriculture: 8(12): 200-220. doi: https://doi.org/ 10.3390/agriculture8120200

Bosco S, Di Bene C, Galli M, Remorini D, Massai R, Bonari E (2011) Greenhouse gas emissions in the agricultural phase of wine production in the Maremma rural district in Tuscany, Italy. Ital J Agron 6(15):93-100. https://doi.org/10.4081/ija.2011.e15

Breidert C, Hahsler M, Reutterer T (2006) A review of methods for measuring willingness-to-pay. Innovative Marketing 2(4):8-32

Breustedt G (2014) Demand for carbon-neutral food - evidence from a discrete choice experiment for milk and apple juice. In: Contributed paper prepared for presentation at the 88th Annual Conference of the Agricultural Economics Society. AgroParisTech, Paris, pp 9-11 April 2014

Bruwer J, Lesschaeve I (2012) Wine tourists' destination region brand image perception and antecedents: Conceptualization of a winescape framework. J Travel Tourism Market 29(7):611-628. https://doi.org/10.1080/10548408.2012.719819

Bruwer J, Pratt MA, Saliba A, Hirche M (2014) Regional destination image perception of tourists within a winescape context. Curr Issues Tour:1-21. https://doi.org/10.1080/13683500.2014.904846

Capitello R, Agnoli L, Charters S, Begalli D (2016) How important is the carbon claim in Generation Y Italians' wine choice? In: Bruwer J, Lockshin L, Corsi A, Cohen J and Hirche M (Eds). Wine business research that matters, 9th Academy of Wine Business Research Conference. University of South Australia, Adelaide, Australia, 17-18 February, 2016. ISBN: 978-0- 
9944460-0-8. Available at https://flore.unifi.it/bitstream/2158/1056390/1/Conference-Proceedings-Final_TOC_Final.pdf Accessed 24 Sept 2018

Carballo Penela A, do Carme García-Negro M, Doménech Quesada JL (2009) A methodological proposal for corporate carbon footprint and its application to a wine-producing company in Galicia, Spain Sustainability 1(2):302-318. https://doi.org/10. 3390/su1020302

Carlsson F, Garcia J, Lofgren A (2010) Conformity and the demand for environmental goods. Environ Resour Econ 47(3):407421. https://doi.org/10.1007/s10640-010-9385-2

Cholette S, Venkat K (2009) The energy and carbon intensity of wine distribution: a study of logistical options for delivering wine to consumers. J Clean Prod 17(16):1401-1413. https://doi.org/10.1016/j.jclepro.2009.05.011

Cleveland DA, Radka NC, Müller NM, Watson TD, Rekstein NJ, Wright HVM, Hollingshead SE (2011) Effect of localizing fruit and vegetable consumption on greenhouse gas emissions and nutrition, Santa Barbara County. Environ Sci Technol 45(10):4555-4562. https://doi.org/10.1021/es1040317

Coff C, Korthals M, Barling D (2008) Ethical traceability and informed food choice. In: Coff C, Barling D, Korthals M, Nielson D (eds) Ethical traceability and communicating food. The International Library of Environmental, Agricultural and Food Ethics, vol 15. Springer, Netherlands, pp 1-18. https://doi.org/10.1007/978-1-4020-8524-6

Cohen MA, Vandenbergh MP (2012) The potential role of carbon labelling in a green economy. Energ Econ 34(S1):S53-S63. https://doi.org/10.1016/j.eneco.2012.08.032

Colman T, Päster P (2009) Red, white, and 'green': the cost of greenhouse gas emissions in the global wine trade. J Wine Research 20(1):15-26. https://doi.org/10.1080/09571260902978493

Council of Europe (2000) European landscape convention. European Treaty Series - No. 176 Florence, 20.X.2000

Čuček L, Klemeš JJ, Kravanja Z (2012) A review of footprint analysis tools for monitoring impacts on sustainability. J Clean Prod 34:9-20. https://doi.org/10.1016/j.jclepro.2012.02.036

Delmas MA, Grant LE (2008) Eco-labeling strategies: the eco-premium puzzle in the wine industry. Working Paper No. 13. AAWE-American Association of Wine Economists

Elliot S, Barth JE (2012) Wine label design and personality preferences of millennials. J. Prod. Brand Manag. 21(3):183-191

Fang K, Heijungs R (2015) Rethinking the relationship between footprints and LCA. Environ Sci Technol 49(1):10-11. https:// doi.org/10.1021/es5057775

Fromm J, Garton C (2013) Marketing to millennials: reach the largest and most influential generation of consumers ever. AMACOM - American Management Association, New, York

Guenther M, Saunders CM, Tait PR (2012) Carbon labelling and consumer attitudes. Carbon Manag J 3(5):445-455. https://doi. org/10.4155/cmt.12.50

Hanley N, Wright RE, Adamowicz V (1998) Using choice experiments to value the environment. Environ Res Econ 11(3-4): 413-428. https://doi.org/10.1023/A:1008287310583

Johnson R, Bruwer J (2007) Regional brand image and perceived wine quality: the consumer perspective. Int J Wine Business Res 19(4):276-297. https://doi.org/10.1108/17511060710837427

Lancaster KJ (1966) A new approach to consumer theory. J Polit Econ 74(2):132-157. https://doi.org/10.1086/259131

Liebe U, Andorfer VA, Gwartney PA, Meyerhoff J (2014) Ethical consumption and social context: experimental evidence from Germany and the United States. University of Bern Social Sciences Working Paper No. 7, 1-49

Louviere JJ, Flynn TN, Carson RT (2010) Discrete choice experiments are not conjoint analysis. J Choice Modelling 3(3):57-72. https://doi.org/10.1016/S1755-5345(13)70014-9

Luce RD (1959) Individual choice behavior: a theoretical analysis. Wiley, New York

McCluskey JJ, Loureiro ML (2003) Consumer preferences and willingness to pay for food labeling: A discussion of empirical studies. J Food Distribution Res 34(3):95-102

McFadden D (1974) Conditional logit analysis of qualitative choice behavior. S. 105-142. In: Zarembka P (ed) Frontiers in Econometrics. Academic Press, New York

Moreno FM, Carreón FA, Moreno S (2016) The adoption of the green marketing in the millennium generation. Int J of Marketing Studies 8(2):97-104

Niccolucci V, Galli A, Kitzes J, Pulselli RM, Borsa S, Marchettini N (2008) Ecological footprint analysis applied to the production of two Italian wines. Agr Ecosyst Environ 128(3):162-166. https://doi.org/10.1016/j.agee.2008.05.015

Noble SM, Haytko DL, Phillips J (2009) What drives college-age generation Y consumers? J Bus Res 62(6):617-628. https://doi. org/10.1016/j.jbusres.2008.01.020

Nowak E, Newton S (2008) Using winery web sites to launch relationships with millennials. Int J Wine Bus Res 20(1):53-67. https://doi.org/10.1108/17511060810864615

Nowak E, Thach L, Olsen J (2006) Wowing the millennials: creating brand equity in the wine industry. J Product Brand Manag 15(5):16-323. https://doi.org/10.1108/10610420610685712

OECD (2016). Agriculture and climate change: towards sustainable, productive and climate-friendly agricultural systems. Background Note 4, available at www.oecd.org/agriculture/ministerial

OIV (2018), World vitiviniculture situation. OIV statistical report on world vitiviniculture, International Organisation of Vine and Wine (OIV), Paris. Available at http://www.oiv.int.

OIV (2019) State of the vitiviniculture world market. State of the sector in 2018. International Organisation of Vine and Wine (OIV), Paris, p 2018 Available at http://www.oiv.int

Olsen J, Thach E, Nowak L (2007) Wine for my generation: exploring how U.S. wine consumers are socialized to wine. J Wine Res 18(1):1-18. https://doi.org/10.1080/09571260701526816

Pattara C, Cichelli A, Civitarese C, Di Martino M (2015) A comparison of carbon footprints in wine production: the case of two cooperative wineries in central Italy. Bulletin de I'OIV 85(977-978-979):307-316

Pattara C, Raggi A, Cichelli A, (2012) Life Cycle Assessment and Carbon Footprint in the Wine Supply-Chain. Environmental Management 49 (6):1247-1258

Pomarici E, Vecchio R (2014) Millennial generation attitudes to sustainable wine: an exploratory study on Italian consumers. J Clean Prod 66(1):537-545. https://doi.org/10.1016/j.aaspro.2016.02.067

Quintal VA, Thomas B, Phau I (2015) Incorporating the winescape into the theory of planned behaviour: Examining 'new world' wineries. Tourism Manage 46:596-609. https://doi.org/10.1016/j.tourman.2014.08.013 
Roos $\mathrm{E}$, Tjarnemo H (2011) Challenges of carbon labelling of food products: a consumer research perspective. Brit Food J 113(8):982-996. https://doi.org/10.1108/00070701111153742

Rousseau S, Vranken L (2013) Green market expansion by reducing information asymmetries: evidence for labelled organic food products. Food Policy 40:31-43. https://doi.org/10.1016/j.foodpol.2013.01.006

Rugani B, Vázquez-Rowe I, Benedetto G, Benetto E (2013) A comprehensive review of carbon footprint analysis as an extended environmental indicator in the wine sector. J Clean Prod 54:61-77. https://doi.org/10.1016/j.jclepro.2013.04.036

Santini C, Cavicchi A, Casini L (2013) Sustainability in the wine industry: key questions and research trends. Agricultural and Food Economics 1(1):1-14. https://doi.org/10.1186/2193-7532-1-9

Smith P., Bustamante M, Ahammad H, Clark H, Dong H, Elsiddig EA, Haberl H, Harper R, House J, Jafari M, Masera O, Mbow C, Ravindranath N.H, Rice C.W, Robledo Abad C, Romanovskaya A, Sperling F, Tubiello F. (2014). Agriculture, Forestry and Other Land Use (AFOLU). In Edenhofer O., Pichs-Madruga R, Sokona Y, Farahani E, Kadner S, Seyboth K, Adler A, Baum I, Brunner S, Eickemeier P, Kriemann B, Savolainen J, Schlömer S, von Stechow C, Zwickel T, Minx J.C. (eds.). Climate Change 2014: Mitigation of Climate Change. Contribution of Working Group III to the Fifth Assessment Report of the Intergovernmental Panel on Climate Change. Cambridge University Press, Cambridge and New York, NY

Soja G, Zehetner F, Rampazzo-Todorovic G, Schildberger B, Hackl K, Hofmann R, Burger E, Omann I (2010) Wine production under climate change conditions: mitigation and adaptation options from the vineyard to the sales booth. In: Darnhofer I and Grötzer M, Building sustainable rural futures: The added value of systems approaches in times of change and uncertainty. Proceedings of the 9th European IFSA Symposium, University of Natural Resources and Applied Life Sciences, Wien:1368-1378

Stigler GJ (1961) The economics of information. J Polit Econ 69(3):213-225. https://doi.org/10.1086/258464

Sudbury-Riley L, Kohlbacher F (2016) Ethically minded consumer behavior: scale review, development, and validation. J Bus Res 69:2697-2710. https://doi.org/10.1016/j.jbusres.2015.11.005

Svanes E, Aronsson AKS (2013) Carbon footprint of a Cavendish banana supply chain. Int J Life Cycle Assess 18(8):1450-1464. https://doi.org/10.1007/s11367-013-0602-4

Teagle J, Mueller S, Lockshin L (2010) How do millennials' wine attitudes and behaviour differ from other generations? 5th International Academy of Wine Business Research Conference, 8-10 February 2010, Auckland (NZ)

Tempesta T (2014) People's preferences and landscape evaluation in Italy: a review. New Medit 13(1):50-59

Tempesta T, Arboretti R, Giancristofaro R, Corain L, Salmaso L, Tomasi D, Boatto V (2010) The importance of landscape in wine quality perception: an integrated approach using choice-based conjoint analysis and combination-based permutation tests. Food Qual Prefer 21(7):827-836. https://doi.org/10.1016/j.foodqual.2010.04.007

Troiano S, Marangon F, Tempesta T, Vecchiato D (2016) Organic vs local claims: substitutes or complements for wine consumers? A marketing analysis with a discrete choice experiment. New Medit 15(2):14-21

Van Doorslaer B, Witzke P, Huck I, Weiss F, Fellmann T, Salputra G, Jansson T, Drabik D, Leip A (2015) An economic assessment of GHG mitigation policy options for EU agriculture. In: Fellmann T (ed) European Commission. Joint Research Centre. Institute for Prospective Technological Studies Luxembourg: Publications Office of the European Union. https://doi.org/10.2791/180800

van Rikxoort H, Schroth G, Läderach P, Rodríguez-Sánchez B (2014) Carbon footprints and carbon stocks reveal climatefriendly coffee production. Agron Sustain Dev 34(4):887-897. https://doi.org/10.1007/s13593-014-0223-8

Vanclay JK, Shortiss J, Aulsebrook S, Gillespie AM, Howell BC, Johanni R, Maher MJ, Mitchell KM, Steward MD, Yates J (2011) Customer response to carbon labelling of groceries. J Consum Policy 34(1):153-160. https://doi.org/10.1007/ s10603-010-9140-7

Veale R, Quester P (2008) Consumer sensory evaluations of wine quality: the respective influence of price and country of origin. J Wine Economics 3(1):10-29. https://doi.org/10.1017/S1931436100000535

Waye V (2008) Carbon footprints, food miles and the Australian wine industry. SSRN Electronic J 9(1). January:2008. https:// doi.org/10.2139/ssrn.2354830

Wedel M, Kamakura WA (2000) Market segmentation: concepts and methodological foundations. Kluwer Academic Publishers, Boston

Wolf M, Thomas S (2007) How millennial, generation X, and baby boomer wine consumers evaluate wine labels. J Food Distribution Research 38(1):170-181

\section{Publisher's Note}

Springer Nature remains neutral with regard to jurisdictional claims in published maps and institutional affiliations.

\section{Submit your manuscript to a SpringerOpen ${ }^{\circ}$ journal and benefit from:}

- Convenient online submission

- Rigorous peer review

- Open access: articles freely available online

High visibility within the field

- Retaining the copyright to your article

Submit your next manuscript at $\boldsymbol{\nabla}$ springeropen.com 